\title{
LEACHING OF URANIUM ORES IN THE PROCESS OF SODIUM SULPHATE ELECTROLYSIS
}

\author{
V.G. Nefedov ${ }^{1}$, Yu.E. Sknar ${ }^{1}$, O.A. Kharytonova ${ }^{2}$

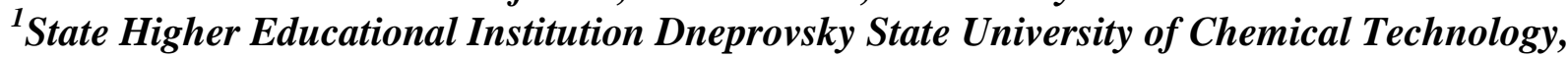 \\ Dnipro, Ukraine \\ E-mail: vnefedov@i.ua,tel.+38-050-732-45-65; \\ ${ }^{2}$ Dneprovsky State Technical University, Kamenskoe, Ukraine, \\ E-mail: eah@ukr.net
}

\begin{abstract}
When uranium is extracted from concentrates with high silicon content, acid leaching is usually used. The disadvantage of this method is the high consumption, high cost and corrosion activity of the reagents. Moreover, for the oxidation of tetravalent uranium to highly soluble hexavalent uranium, it is necessary to process it with oxidizing agents, for example, oxygen. The work shows the possibility of development and chemical concentration of uranium ores using electrolysis of sodium sulfate. During electrolysis the $\mathrm{pH}$ in the anode chambers ranges from $2.2 \ldots 2.5$ to $0.5 \ldots 0.7$ in the near-electrode layer of the electrolyte, which corresponds to the $\mathrm{pH}$ range during leaching in agitators. Oxygen released at the anode is able to oxidize uranium to hexavalent one.
\end{abstract}

\section{INTRODUCTION}

Uranium in nature is mainly found in granites, pegmatites and hydrothermal deposits. Uranium in its compounds can be trivalent, tetravalent, quinquevalent, and hexavalent. The compounds of tetravalent and hexavalent uranium with oxygen: $\mathrm{UO}_{2}, \mathrm{UO}_{3}, \mathrm{U}_{3} \mathrm{O}_{8}$, $\mathrm{UO}_{4} \cdot 2 \mathrm{H}_{2} \mathrm{O}$ are of the greatest importance, as well as the uranyl anion $\mathrm{UO}_{2}{ }^{2+}$. There are also minerals that are the salts of oxygen acids.

Uranium feedstock passes through several successive stages of processing: dressing, chemical concentration and extraction treatment.

At the first stage of uranium ore dressing, the radiometric method, which allows waste rock separation that does not have radioactive emission, is used, as well as gravity and flotation methods.

The second stage of dressing is the concentration carried out by the hydrometallurgical method, at the first stage of which calcination can be carried out for sulfide ores. The leaching process is carried out in agitators with mechanical agitation, or in autoclaves at elevated pressure. Sorption leaching of uranium is possible in capacities with air mixing. Most of the minerals containing uranium dissolve in mineral acids and hot solutions of alkali metal carbonates. The final products of uranium plants are "yellow cake" concentrate with uranium content of $55 \ldots 60 \%$, and uranium protoxide-oxide with uranium content of more than $84 \%$.

In nuclear purity fuel, the content of impurities should be no more than $10^{-3} \ldots 10^{-6} \%$. This is due to the fact that the impurities of $\mathrm{Fe}, \mathrm{Si}, \mathrm{P}, \mathrm{V}, \mathrm{Al}, \mathrm{Mn}, \mathrm{B}$, rareearth metals and other substances found in uranium ores are distinguished by a large effective cross section for thermal neutron capture. Their presence in nuclear fuel reduces its efficiency. Sorption, precipitation, and extraction methods are used for cleaning of these impurities during the finishing treatment of uranium concentrates.

Uranium compounds are extracted from ores at the stages of leaching and sorption concentration. The tendency of uranium compounds to complex formation with oxygen-containing molecules ensures the selectivity of its extraction during sorption. There are a lot of minerals containing uranium and the technology of leaching with acidic or alkaline carbonate solutions is selected for each of them. When uranium is extracted from high calcium concentrates, carbonate leaching should be used. The ores of the Zheltue Vodu deposit, in which uranium is contained in granites, are characterized by a high content of silicon and iron. It is advisable to carry out their processing by acid leaching [1].

Concentrated sulfuric and nitric acids interact with uranium slowly, diluted sulfuric acid with oxidizing agents dissolves uranium quickly. The leaching of hexavalent uranium takes place according to the reaction:

$$
\mathrm{UO}_{3}+\mathrm{H}_{2} \mathrm{SO}_{4}=\mathrm{UO}_{2} \mathrm{SO}_{4}+\mathrm{H}_{2} \mathrm{O} .
$$

Since tetravalent uranium practically does not dissolve in acids, its leaching is carried out with oxidizing agents, nitric acid, sodium nitrate or pyrolusite. It is also possible to use oxygen at an overpressure of up to $7 \ldots 14 \mathrm{~atm}$. In this case, the reaction happens with the formation of the hexavalent compound of uranium, which is readily soluble in water and the consumption of sulfuric acid decreases:

$$
\mathrm{UO}_{2}+\frac{1}{2} \mathrm{O}_{2}+\mathrm{H}_{2} \mathrm{SO}_{4}=\mathrm{UO}_{2} \mathrm{SO}_{4}+\mathrm{H}_{2} \mathrm{O} .
$$

It is impossible to obtain anhydrous sulfate by reactions (1) and (2), the product of these reactions is a cationic aquacomplex $\left[\mathrm{UO}_{2}\left(\mathrm{H}_{2} \mathrm{O}\right)_{6}\right]^{2+}$ or neutral aquacomplexes $\left[\mathrm{UO}_{2}\left(\mathrm{H}_{2} \mathrm{O}\right)_{4} \mathrm{SO}_{4}\right],\left[\mathrm{UO}_{2}\left(\mathrm{H}_{2} \mathrm{O}\right)_{3} \mathrm{SO}_{4}\right]_{n}$, $\left[\mathrm{UO}_{2}\left(\mathrm{H}_{2} \mathrm{O}\right)_{2} \mathrm{SO}_{4}\right],\left[\mathrm{UO}_{2}\left(\mathrm{H}_{2} \mathrm{O}\right) \mathrm{SO}_{4}\right]_{n}$.

For acid leaching, crushed ore to $60 \%-200$ mesh $(0.074 \mathrm{~mm})$ is used. It is processed in a cascade of agitators for approximately $48 \ldots 60 \mathrm{~h}$ at an initial $\mathrm{pH}$ of $0.5 \ldots 0.7$ and a final $\mathrm{pH}$ of $1.8 \ldots 2.5$.

The disadvantages of acid leaching include the high consumption of reagents per unit of extracted uranium. Therefore, the main parameter for choosing reagents is their cost, the duration of the processing, and the degree 
of uranium extraction. Most often, the industry uses sulfuric acid which is the most affordable, but still expensive and aggressive at low concentrations.

To reduce the cost of the leaching process, it is proposed to obtain sulfuric acid directly in reactors using sulfide ores by the reactions:

$$
\begin{gathered}
\mathrm{FeS}_{2}+3.5 \mathrm{O}_{2}+\mathrm{H}_{2} \mathrm{O} \rightarrow \mathrm{FeSO}_{4}+\mathrm{H}_{2} \mathrm{SO}_{4}, \\
\left(\mathrm{FeSO}_{4}+0.5 \mathrm{O}_{2}+\mathrm{H}_{2} \mathrm{SO}_{4} \rightarrow \mathrm{Fe}_{2}\left(\mathrm{SO}_{4}\right)_{3}+\mathrm{H}_{2} \mathrm{O},\right. \\
\mathrm{UO}_{2}+\mathrm{Fe}_{2}\left(\mathrm{SO}_{4}\right)_{3} \rightarrow 2 \mathrm{FeSO}_{4}+\mathrm{UO}_{2} \mathrm{SO}_{4}, \\
\mathrm{Fe}_{2}\left(\mathrm{SO}_{4}\right)_{3}+6 \mathrm{H}_{2} \mathrm{O} \rightarrow 2 \mathrm{Fe}(\mathrm{OH})_{3}+3 \mathrm{H}_{2} \mathrm{SO}_{4}
\end{gathered}
$$

Electrolysis of cheaper sodium sulfate in electrolyzers with separated electrode spaces is the other option for producing sulfuric acid directly in the reactor and, accordingly, reducing leaching costs, which account for up to $40 \%$ of the production cost. In this case, the reaction of yielding oxygen and acidification of the solution takes place at the anode,

$$
\mathrm{H}_{2} \mathrm{O}+\mathrm{Na}_{2} \mathrm{SO}_{4}-2 e \rightarrow 0.5 \mathrm{O}_{2}+\mathrm{H}_{2} \mathrm{SO}_{4}
$$

and at the cathode - hydrogen yielding and alkalization of the medium

$$
2 \mathrm{H}_{2} \mathrm{O}+\mathrm{Na}_{2} \mathrm{SO}_{4}+2 e^{-} \rightarrow \mathrm{H}_{2}+2 \mathrm{NaOH} .
$$

Sodium sulfate does not decompose during electrolysis, but $\mathrm{SO}_{4}{ }^{2}$-ions in the anode space provide the formation of sulfuric acid.

The advantages of the method include the low cost of raw materials and electricity, low corrosivity, and the constant generation of $\mathrm{H}^{+}$-ions in the electrolysis process. The disadvantages are the relatively low concentration of acid in the anode chamber, which is related with the migration and diffusion transfer of $\mathrm{H}^{+}$and $\mathrm{OH}^{-}$-ions from the cathode chamber towards each other and their mutual neutralization. To reduce the diffusion and migration transfer of $\mathrm{H}^{+}$- and $\mathrm{OH}^{-}$-ions, it is advisable to use solutions with the highest possible concentration of indifferent carrier ions, in this case sodium ions and sulfate ions. As acid and alkali accumulate in the electrode chambers, the transport numbers of $\mathrm{H}^{+}$- and $\mathrm{OH}^{-}$-ions increase, which limits the value of the achieved $\mathrm{pH}$ value. In addition, the $\mathrm{pH}$ value varies with time depending on the magnitude of the electrolyte volume in the electrode chambers and the current strength.

The aim of this work is to assess the possibility of using sodium sulfate electrolysis to produce sulfuric acid and leaching of uranium-containing ores.

\section{EXPERIMENTAL TECHNIQUE}

During the experiments, we studied the change in $\mathrm{pH}$ in the anode space of the electrolyzer and acidity in the anode layer of the electrolyte.

Sodium sulfate was electrolyzed in electrolysis cells with separation of electrode spaces by ion-exchange membranes. The electrodes used were stainless steel cathodes and titanium dioxide manganese anodes (TDMA). The change in acidity was monitored by $\mathrm{pH}$ meter. Sodium sulfate with concentration of $15,30,50$, 70 , and $150 \mathrm{~g} / \mathrm{l}$ was used as a solution in the anode space, and the same solutions were used in the cathode, or a solution of sodium hydroxide with a concentration of $20 \mathrm{~g} / \mathrm{l}$. The current load varied from 0.5 to $3 \mathrm{~A}$. The volume of electrolyte in the electrode chambers was 0.51 .

A variation of the sampling method was used for assessment of the $\mathrm{pH}$ of the anode layer. The main point was the following: a pre-weighed platinum working electrode with an area of $1.5 \mathrm{~cm}^{2}$ was suspended on the beam of a torsion balance. The electrode was connected to a potentiostatic power supply circuit and was removed from the solution under current. The current density on the electrode varied from 100 to $10.000 \mathrm{~A} / \mathrm{m}^{2}$. After extraction from the solution, the electrode was weighed with a wetting liquid film. The difference in the weight of the dry and wetted electrodes was used to determine the mass of the solution on the electrode, after that its thickness was calculated. The solution from the electrode surface was washed off with a fixed amount of distilled water (one milliliter), and the content of $\mathrm{H}^{+}$-ions was determined by titration in it. Methyl red was used as an indicator ( $\mathrm{pH}$ of the color transition $4.5 \ldots 5.5$ ). The titrant was a $0.01 \mathrm{~mol} / \mathrm{l}$ $\mathrm{NaOH}$ solution. In the measurements, it was believed that the density of the solution extracted on the surface of the electrode is equal to the density in the volume of the electrolyte. The concentration of these ions in the liquid film and on the electrode surface was calculated by the number of $\mathrm{H}^{+}-$or $\mathrm{OH}^{-}$-ions and the volume of the electrolyte.

\section{EXPERIMENTAL RESULTS AND DISCUSSION}

\subsection{CALCULATION OF THE SULFURIC ACID CONCENTRATION DURING THE ELECTROLYSIS OF $\mathrm{Na}_{2} \mathrm{SO}_{4}$}

The following assumptions were made to calculate surface ion concentrations and $\mathrm{pH}$ in sodium sulfate solutions.

The distribution of the $\mathrm{H}+$-ions concentration in the near-electrode layer of the electrolyte is uneven. It is maximal on the electrode surface and is equal to the concentration in the volume outside the diffusion layer. To determine the concentration at the electrode surface, it was assumed that the concentration in the diffusion layer varies linearly. It was also assumed that the thickness of the diffusion layer is commensurate with the film thickness on the electrode surface. In this case, the total number of ions per unit electrode surface is

$$
N_{T}=\int_{0}^{\delta_{\text {dif }}}\left(N_{S}-\frac{N_{S}-N_{0}}{\delta_{d i f}} \delta\right) d \delta,
$$

where $\delta_{\text {dif }}$ is the thickness of the diffusion layer; $\mathrm{N}_{\mathrm{S}}, \mathrm{N}_{0}$ is the number of ions at the electrode surface and in the depth of the solution

The solution of this equation with respect to the number of ions at the electrode surface gives

$$
N_{S} \frac{\delta_{d i f}}{2}=N_{T}-N_{0} \frac{\delta_{d i f}}{2}
$$

or

$$
N_{S}=\frac{2 N_{T}-N_{0} \delta_{d i f}}{\delta_{d i f}} .
$$

Passing to the concentrations, we obtain 


$$
C_{S}=\frac{2 C \delta_{d i f}-C_{0} \delta_{d i f}}{\delta_{d i f}},
$$

where $C_{\mathrm{S}}$ is the concentration of acid on the surface of the electrode; $C$ is the concentration in the nearelectrode layer; $C_{0}=10^{-4} \ldots 10^{-7}$ is the concentration in the electrolyte volume.

\subsection{ESTIMATES OF PH CHANGES IN THE ANODE CHAMBER}

The $\mathrm{pH}$ during electrolysis was measured discretely, with a frequency of $1 \ldots 2 \mathrm{~min}$. To go over to the conditions of industrial electrolysis with an arbitrary volume of electrolyte, a change in $\mathrm{pH}$ was constructed depending on the amount of transmitted electricity per unit volume of electrolyte. The dynamics of $\mathrm{pH}$ changes in a solution with a concentration of $15 \mathrm{~g} / \mathrm{l}$ and at current loads from 0.5 to $3 \mathrm{~A}$ is shown in Fig. 1. It follows from the figure that, despite the different rate of change in $\mathrm{pH}$ in the first minutes of electrolysis at different current loads, reaching a stationary $\mathrm{pH}$ occurs when $1 \mathrm{~A} \cdot \mathrm{h}$ passes the amount of electricity per liter of solution in the anode chamber. The $\mathrm{pH}$ in this case is about $1.94 \ldots 2.30$, which corresponds to the final $\mathrm{pH}$ values during leaching with sulfuric acid.

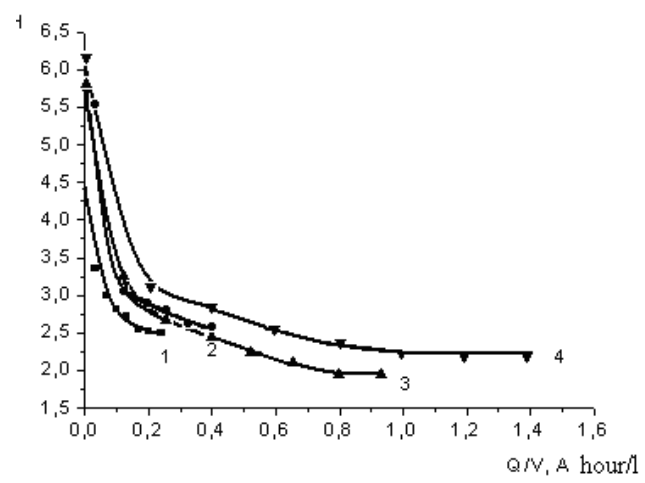

Fig. 1. The dependence of $p H$ changes in the anode chamber of the electrolyzer on the specific amount of electricity. A solution of $\mathrm{Na}_{2} \mathrm{SO}_{4}$ concentration of $15 \mathrm{~g} / \mathrm{l}$.

Current load, A: $1-0.5 ; 2-1 ; 3-2 ; 4-3$

At the same time, it should be noted that acid during electrolysis is constantly generated throughout the leaching period, in contrast to the leaching in the cascade of agitators. The advantages of this method include the lower aggressiveness of the solutions used and the constant generation of oxygen necessary for the oxidation of tetravalent uranium. In addition, in the near-electrode layer, the concentration of dissolved gas exceeds the saturation concentration by about an order of magnitude. This is due to the need for supersaturation during the formation of a gas bubble nucleus [2].

In addition to the above experiments, the effect of the concentration of sodium sulfate solution on the stationary $\mathrm{pH}$ value was estimated (Fig. 2).

From the figure it follows that with an increase in the concentration of the solution, the rate of $\mathrm{pH}$ change decreases, but the effect of the concentration of sodium sulfate on the concentration of acid (of the $\mathrm{pH}$ solution) is negligible. Therefore, the choice of the working concentration of sodium sulfate will be determined by the conditions of electrolysis and ore leaching.

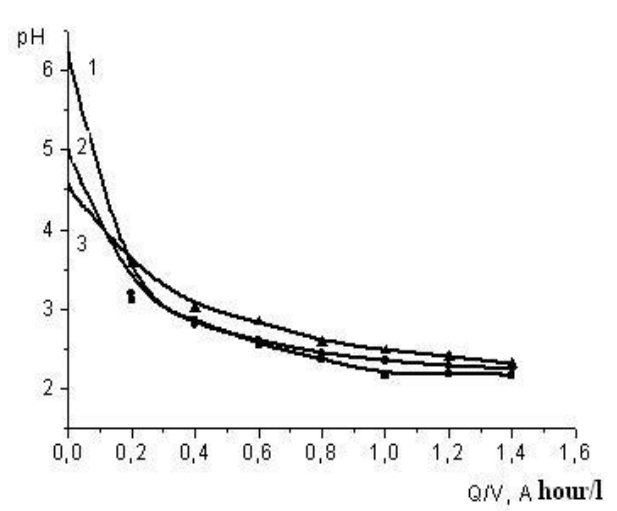

Fig. 2. The $p H$ changing of sodium sulfate solution in the anode chamber of the electrolyzer, depending on the amount of electricity per unit volume of electrolyte.

Concentration, $g / l: 1-15 ; 2-50 ; 3-70$

So, with increasing concentration, the electrical conductivity of solutions increases and the cost of electricity for electrolysis decreases.

In addition, with solution concentration increasing, the solubility of oxygen in it decreases. We can assume and this was confirmed by the experiment that the concentration of sodium sulfate in industrial electrolysis will vary from 15 to $150 \mathrm{~g} / \mathrm{l}$ (approximately, from 0.1 to $1 \mathrm{~mol} / \mathrm{l})$.

The decrease in $\mathrm{pH}$ in the anode chamber of the electrolyzer occurs due to the transfer of $\mathrm{H}^{+}$-ions from the electrode surface to the volume of the electrolyte. In this case, it is of interest to determine the $\mathrm{pH}$ in the near-electrode layer and on the surface of the electrodes.

\subsection{THE DEPENDENCE OF THE PH CHANGE AT THE ANODE SURFACE ON THE CURRENT DENSITY}

The experiments showed that the thickness of the wetting film on the electrode surface, calculated by the weight gain, in different experiments, varied within $0.1 \ldots 0.2 \mathrm{~mm}$. This is really close to the thickness of the diffusion layer, which was stated earlier. During electrolysis, the acid concentration in this layer increases with increasing current density and depends on the concentration of the initial solution. The density dependences of the acid concentration at the anode surface calculated according to (1) for the upper and lower possible concentrations of sodium sulfate are shown in Fig. 3.

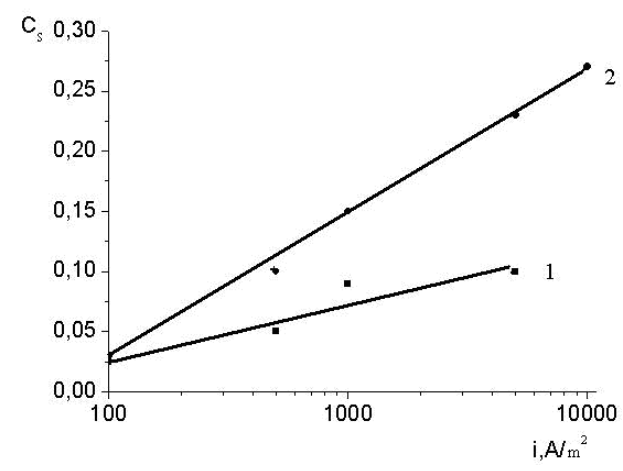

Fig. 3. Dependence of acid concentration on the anode surface on current density.

The concentration of sodium sulfate, $\mathrm{g} / \mathrm{l}: 1-15 ; 2-150$ 
It follows from the figure that the surface concentration of $\mathrm{H}^{+}$-ions increases in proportion to the logarithm of the current density and at a current density of, for example, $1000 \mathrm{~A} / \mathrm{m}^{2}$ and a concentration of $150 \mathrm{~g} / \mathrm{l}$, reaches $0.2 \ldots 0.3 \mathrm{~mol} / \mathrm{l}$. This approximately corresponds to a $\mathrm{pH}$ of $0 \ldots .0 .7$, which is comparable with the initial $\mathrm{pH}$ of the medium during leaching in agitators.

To use the advantages of electrolysis during the leaching of silicate uranium ores, it is advisable to use wire or mesh anodes uniformly distributed in the volume of the apparatus. This will ensure the contact of the particles of the suspension solid phase with the electrode surface, where the acid concentration is high. The following ratios can be initial data for preliminary calculations.

For the internal volume of $V_{\mathrm{A}}$ anolyte and hourly acid productivity, the current load is:

$$
I=\frac{V_{A} \tau}{Q_{S P}},
$$

where $V_{\mathrm{A}}$ is the volume of electrolyte in liters, $Q_{\mathrm{SP}} \sim 1(\mathrm{~A} \cdot \mathrm{h}) / 1$ is the specific amount of electricity necessary to obtain a constant concentration of acid in the anode chamber. The area of the electrodes will be, $\mathrm{m}^{2}$ :

$$
S=\frac{I}{i},
$$

where $i$ is the selected current density, $\mathrm{A} / \mathrm{m}^{2}$.

For example.

For electrolysis, we choose a rectangular electrolyzer. The anode chamber is located in the center, and the cathode cells are located on two sides. This allows you to assemble a filter-press structure with the serial connection of any number of unit cells "cathodeanode-cathode-anode-cathode ..." (Fig. 4). To reduce thevoltage drop in the electrolyte, it is advisable to make the thickness of the anode chamber small, for example, $100 \mathrm{~mm}$. Consider an electrolyzer with dimensions of $1000 \times 1000 \times 100 \mathrm{~mm}$ and an electrolyte volume of 1001 . In this case the current load on one anode chamber will be (2) $100 \mathrm{~A}$. When using a current density of $1000 \mathrm{~A} / \mathrm{m}^{2}$, the area of the anode (3) will be $0.1 \mathrm{~m}^{2}$.

If we use the metal oxide electrodes based on a titanium wire, with a diameter of, for example, $d=1 \mathrm{~mm}$ as anode material, then its length will be equal to

$$
l=\frac{S}{\pi d} \approx 30 \mathrm{~m} .
$$

In the electrolyzer with a width of $1 \mathrm{~m}$, this will make it possible to make an anode consisting of 5 wires in a row and 6 rows located at different heights.

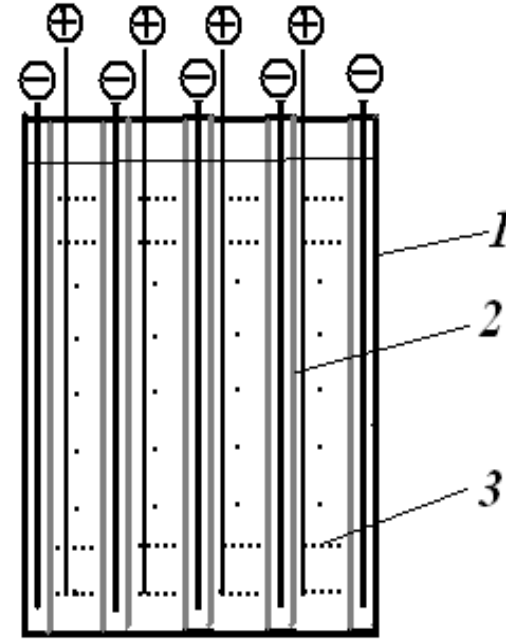

Fig. 4. Schematic diagram of the electrolyzer for the electrolysis of sodium sulfate solution: 1 - case; 2 - ion exchange membrane; 3 - mesh or wire anodes

Based on the results obtained, the following conclusions can be drawn.

\section{FINDINGS}

1. The electrolysis of sodium sulfate solution allows you to get acid in the anode chamber in the $\mathrm{pH}$ range from $0.5 \ldots 0.7$ to $2 \ldots 2.5$, which corresponds to the $\mathrm{pH}$ range of the medium during leaching of uraniumcontaining ores in the agitators.

2. The high concentration of dissolved oxygen in the electrode layer eliminates the use of pyrolusite for the oxidation of $\mathrm{U}^{4+}$ in $\mathrm{U}^{6+}$.

3. The proposed design of the electrolyzer for the electrolysis of sodium sulfate allows you to provide the optimal range of $\mathrm{pH}$ and the concentration of dissolved oxygen for the leaching of uranium ores.

4. The selected parameters of sodium sulfate electrolysis provide the transition degree of uranium of the ore from the solid phase into the solution at the level of $90 \%$.

\section{REFERENCES}

1. V.V. Shatalov, I.P. Smirnov, A.A. Matveev, K.M. Smirnov. Leaching of uranium and complex ores. // Non-ferrous metals. 2003, N 4, p. 27-34

2. V.G. Nefedov. The evolution of the gas phase during the electrolysis of water in the fields of mass and electric forces. Dnepropetrovsk: UGHTU, 2008, p. 292.

Article received 14.01.2019

\section{ВСКРЫТИЕ УРАНОВЫХ РУД В ПРОЦЕССЕ ЭЛЕКТРОЛИЗА СУЛЬФАТА НАТРИЯ}

\section{В.Г. Нефедов, Ю.Е. Скнар, Е.А. Харитонова}

При извлечении урана из концентратов с высоким содержанием оксида кремния обычно применяется кислотное выщелачивание. Недостатками такого способа являются большой расход, высокая стоимость и коррозионная активность реагентов. При этом для окисления четырехвалентного урана до хорошо 
растворимого шестивалентного необходима операция его обработки окислителями, например, кислородом. В работе показана возможность вскрытия и химического концентрирования урановых руд с помощью электролиза сульфата натрия. $\mathrm{pH}$ в анодных камерах при электролизе колеблется от $2,2 \ldots 2,5$ до $0,5 \ldots 0,7$ в приэлектродном слое электролита, что соответствует диапазону $\mathrm{pH}$ при выщелачивании в агитаторах. Выделяющийся на аноде кислород способен окислять уран до шестивалентного.

\section{РОЗКРИТТЯ УРАНОВИХ РУД У ПРОЦЕСІ ЕЛЕКТРОЛІЗУ СУЛЬФАТУ НАТРІЮ}

\section{В.Г. Нефьодов, Ю.С. Скнар, О.А. Харитонова}

Під час вилучення урану з концентратів з високим вмістом оксиду кремнію зазвичай застосовується кислотне вилуговування. Недоліками такого способу $є$ велика витрата, висока вартість і корозійна активність реагентів. При цьому для окислення чотирьохвалентного урану до добре розчинного шестивалентного необхідна операція його обробки окислювачами, наприклад, киснем. У роботі показана можливість розтину і хімічного концентрування уранових руд за допомогою електролізу сульфату натрію. pH в анодних камерах при електролізі коливається від 2,2..2,5 до 0,5 .0,7 в приелектродному шарі електроліту, що відповідає діапазону рН при вилуговуванні в агітаторах. Кисень, що виділяється на аноді, здатний окислювати уран до шестивалентного. 